\title{
Menggagas Fikih Responsif: Upaya Progresif Modernisasi Fikih
}

\author{
Maulidi
}

\begin{abstract}
Initiating Responsive Fikih (Islamic Jurisprudence): Progressive Efforts to Modernize Fikih. This article discusses the modernization of fiqh in an effort to respond changes and developments in society. The aim is to find a solution to the legal problem (Islam), which so far seems stagnant. This study found 3 causative factors, namely: first, the law is understood as a single entity that is not linked to other entities. In fact, the reality is that the law is closely related to other disciplines. Second, the law is understood as being untouchable, even though the law goes hand in hand with the development of reality. Third, the law is always based on normative textualism, even though there is much local wisdom that also carries philosophical values that are relevant to the legal purpose. This false assumption must begin to be deconstructed, otherwise, there will be empty space in the law (Islam). As a solution, the integrative system approach must be promoted through the transformation of taqlid qauli towards taqlid manhaji, from the linearist paradigm to the teleological paradigm.
\end{abstract}

Keywords: fiqh modernization, responsive, change in society, modernization, fikih, local wisdom

\begin{abstract}
Abstrak: Menggagas Fikih Responsif: Upaya Progresif Modernisasi Fikih. Artikel ini membahas modernisasi fiqh dalam upaya merespon perubahan dan perkembangan masyarakat. Tujuannya untuk mencari solusi terhadap problematika hukum (Islam), yang selama ini terkesan stagnan. Studi ini menemukan 3 faktor penyebab, yakni: pertama, hukum difahami sebagai single entity yang tidak terpaut dari entitas lainnya. Padahal realitasnya, hukum berkait erat dengan disiplin ilmu yang lain. Kedua, hukum difahami sebagai suatu yang bersifat final (untouchable), padahal hukum berjalan beriringan dengan perkembagan realitas. Ketiga, hukum selalu didasarkan pada tektualis normatif, padahal banyak kearifan lokal (local wisdom) yang juga mengusung nilai-nilai filosofis yang relevan dengan maqasid syariah (legal purpose). Asumsi yang keliru ini harus mulai didekonstruksi, jika tidak maka akan terjadi empty space dalam hukum (Islam). Sebagai solusinya, pendekatan integrative system harus mulai digalakkan melalui transformasi taqlid qauli menuju taqlid manhaji, dari paradigma leteralis menuju paradigma teleologis.
\end{abstract}

Kata Kunci: modernisasi fikih, responsif, perubahan sosial, modernisasi, fikih, kearifan lokal

Dosen IIQ An-Nur Bantul Yogyakarta

E-mail: maulidialhasany@gmail.com 


\section{Pendahuluan}

Agama selalu "ditantang" untuk bisa hidup eksis. Di satu sisi, agama selalu diharapkan memiliki signifikansi moral (morality) dan kemanusiaan (humanity) bagi keberlangsungan hidup umat manusia. Namun di sisi lain, agama dipandang secara sinis tidak bisa mengimbangi hegemoni modernitas yang terus berkembang, sehingga muncul kesan negatif is religion compatible with modernity?. Padahal, dalam dunia yang sangat kompleks ini, peran agama tidak bisa dipandang sebelah mata. Kehidupan yang sangat dinamis ini merupakan realitas yang tidak bisa dihindari dan perlu direspon dalam konstruksi pemahaman agama yang dinamis pula. Tarik-menarik antara tradisi (pemahaman agama) dan modernitas menjadi wacana yang masih hangat untuk selalu diperdebatkan. ${ }^{1}$

Fikih adalah bagian dari pemahaman keagaman. Fikih tidak bersifat final. Fikih lebih bersifat dinamis dan fleksibel, selalu dituntut mengalami

${ }^{1}$ Wacana agama dan modernitas terus mengalami dinamika tarik menarik pemikiran. Berbagai ulasan terkait hal tersebut dalam dilihat dalam karya Husnul Muttaqin. "Relasi Agama dan Modernitas: Menggugat Teori Sekularisasi." Jurnal Sosiologi Islam 2, no. 2 (2012). Asma Luthfi. "Aji Modereng Dialektika Agama dan Modernitas pada Masyarakat Bugis di Pedesaan." Cultural Studies di PTAI: Teori dan Praktik. Bunga Rampai 1, no. 1 (2016): h. 1-6. Burhanuddin Daya. Agama Dialogis: Merenda Dialektika Idealita dan Realita Hubungan Antar Agama. Mataram-Minang Lintas Budaya, 2004. Agus Nurhadi. "Busana Muslim Seksi: Antara Modernitas dan Komersialisasi Agama." Dalam Jurnal Analisa 20 (2005). Muhammad Ihsan. "Pendidikan Islam dan Modernitas di Timur Tengah: Studi Kasus Mesir." Hunafa: Jurnal Studia Islamika 4, no. 2 (2007): h. 129142. Muhammad Anis. "Spiritualitas di Tengah Modernitas Perkotaan." Jurnal Bayan 2, no. 4 (2013). Hamdi, Ahmad Zainul. "Agama di Tengah Jaring-jaring Dunia Modern.” Religió: Jurnal Studi Agama-agama 3, no. 2 (2013). Enung Asmaya. "Modernitas dan Tantangannya terhadap Pelaksanaan Dakwah." Komunika: Jurnal Dakwah dan Komunikasi 3, no. 1 (2009): h. 46-62. Ahmad Sahidah. "Menemukan Islam Otentik: Menggugat Tradisi dan Modernitas." Kontekstualita: Jurnal Penelitian Sosial Keagamaan 25, no. 2 (2010). M. Lutfi Mustofa. "Pembaruan Pemikiran Islam Indonesia: Negosiasi Intelektual Muslim dengan Modernitas.” Ulul Albab Jurnal Studi Islam (2013), Robby Habiba Abro. "Identitas Islamis dalam Tegangan dan Negosiasi Antara Dogma dan Modernitas: Resepsi Komunitas Salafi di Yogyakarta Terhadap Fenomena Ghibah Infotainment." PhD diss., Universitas Gadjah Mada, 2014. Irwansyah. "Modernisme, Fundamentalisme Agama dan Terorisme." Miqot: Jurnal Ilmu-ilmu Keislaman 33, no. 2 (2009). Abdul Munir Mulkhan. "Spiritualisasi Lingkungan Materiel dan Moral Kenabian dalam Modernitas." Unisia 30 (2016): h. 35-48. Prihatanto. "Agama, Modernisasi, dan Teori Kritis: Sebuah Potret Pertautan." Unisia 30, no. 64 (2007). Mohammad Hasan Basri. "Ritual Ya Qowiyu: Pergulatan Makna Modernitas, Agama, Budaya Lokal dan Kapitalisme." El-Harakah 11, no. 2 (2009). Andi Fadlan. "Sains dan Agama Dialog Untuk Saling Menguatkan.” Progres 4, no. 1 (2016). Sirajudin. "Integrasi Agama dan Sains; Islamisasi Sains di Tengah Arus Modernitas." Qolamuna: Jurnal Studi Islam 2, no. 1 (2016): h. 77-98. Arifinsyah. "Respons Islam dan Kristen terhadap Modernitas." Journal Analytica Islamica 3, no. 2 (2014): h. 274-295. 
the grand process of modernization. Hal ini senada dengan pernyataan Scott Gordon tentang progresifitas, di mana segala sesuatu akan mengalami evolusi, perpindahan atau perubahan. "All must change, to something new and to something strange." Demikian juga fikih harus bersifat progresif bukan regresif, memiliki sensitifitas responsif-purposif bukan represifoportunis.

Dalam sejarah, dinamika dan fleksibelitas fikih ditunjukkan dengan banyaknya varian mazhab dan karya fikih yang ada. Dinamika transformasi fikih dengan sendirinya menolak asumsi wacana tertutupnya pintu ijtihad (insidad bab al-ijtihâd) dan wacana jumud (intellectual discontinuity). ${ }^{3}$ Karenanya, untuk tetap eksis dan menemukan relevansinya, fikih tidak cukup dibaca sebagai model of reality (bersifat pasif) tetapi juga sebagai model for reality (bersifat aktif). Dalam arti yang terakhir ini, fikih harus responsif terhadap realitas.

Memang, idealnya fikih lahir dari proses integrasi dialektik antara nas, akal dan realitas. ${ }^{4}$ Sebab, setiap era memiliki problematikanya masingmasing, tidak terkecuali era modern. Realitas era modern (ditandai dengan majunya ilmu pengetahuan dan teknologi) tidak bisa dinafikan dari obyek kajian fikih. Realitas perlu mendapat respons positif dari para mujtahid akademik yang relevan dengan konteksnya, sehingga tidak terjadi kekosongan hukum. Karena harus diakui, literatur-literatur fikih klasik tidak cukup memadahi untuk menjawab problematika kontemporer yang terus berkembang. Solusinya, perlu keberanian mujtahid akademik kontemporer untuk melakukan reformulasi teoritik ijtihad (fikih) dan

${ }^{2}$ Scott Gordon. The History and Philosophy of Social Science (Routledge, 1991), h. 148-154.

${ }^{3}$ WB. Hallaq menilai pintu ijtihad tidak pernah tertutup, secara teoritis maupun secara praktis. Hal ini terbukti dalam sejarah bahwa pada akhir abad ke IV, ada beberapa intelektual yang mengkritisi pemikiran imam mazhabnya seperti Ibn Hasan at-Tanukhi penganut Mazhab Hanafi, Ali bin Husain bin Harbawaih penganut Mazhab Syafi'i. Bahkan ada pula yang secara keras menentang taklid seperti Abdul Jabbar dan Al-Basri. Lihat Fauzi. Hallaq: Sejarah Teori Hukum Islam (Jakarta: Prenada Media, 2018). Namun demikian, harus diakui pula bahwa produk kitab era skolastik merupakan komentar atau elaborasi dari karya sebelumnya. Karya-karya fikih yang berkembang pada masa itu hanyalah produk pembacaan tautologis atau pengulangan yang terus-menerus (qirâah mutakarrirah), bukan pembacaan produktif inovatif (qirâah muntijjah mubdiah). Oleh sebab itu, wajar bila Kenneth E. Nollin menyebut karya-karya para sarjana fikih pada masa ini sebagai "corpus of conservative tradisionalisme.

${ }^{4}$ Wahbah Zuhaili. Taghayyur Al-Ijtihâd (Damaskus: Darl al-Maktabi, 2000), h. 8-9. 
rekonstruksi metodologis yang lebih acceptable and compatible with contemporary issues of Islamic legal studies. ${ }^{5}$

Upaya progresifitas hukum Islam dinilai Wahhab Khallaf sebagai suatu keharusan. Alasannya, "teks-teks Alquran dan dan al-sunnah terbatas dan telah final”. Sedangkan realitas sosial dan problematikanya tidak terbatas dan terus berkelanjutan. Maka tidak mungkin "teks-teks yang terbatas" menjadi satu-satunya sumber legislasi dari "teks-teks yang tak terbatas" (inna nusûs al-qurân wa as-sunnah mahdûdah wa mutânahiyah wa waqâiu al-nas wa aqdiyatuhum ghair mahdûdah wa la mutânahiyah falâ yumkin an takûna an-nusus al-mutânahiyah wahdaha hiya al-masdar al-tasyrî̀ li mâ lâ yatanâha). ${ }^{6}$ Dengan kata lain, bahwa ijtihad adalah suatu hal yang darûri (urgen) dalam istimbâth hukum Islam (rechtsvinding). ${ }^{7}$ Sebab masyarakat terus berkembang dengan sejumlah persoalan hukum yang dibawanya tanpa ada legitimasi nas yang rigid (mufassal). ${ }^{8}$

\section{Revitalisasi Turâst dan Signifikansi Tajdîd}

Para Islamolog memiliki perspektif yang berbeda dalam membaca turast. Dalam hal ini ada tiga kelompok: 1). Kelompok yang fanatik tanpa kritik terhadap turâst (legal positivism), tanpa analisis komprehensif atas bangunan epistemologis dan metodologisnya. Sikapnya yang mengisolasi diri dari modernitas membuatnya terjebak dalam ortodoksi konservatif, tidak produktif, serta hanya melahirkan pola pembacaan regresif-tautologis. 2). Kelompok liberalis yang apatis terhadap turâst. Sikapnya yang reduksionis merongrong substansi turâst dan berkutat pada sisi objek materil-empirik an sich (legal realism). 3). Kelompok kompromis antara turâst dan modernitas dengan memadukan dua pendekatan metodologis secara integratif; Timur dan Barat (manâhij wa adâwat muâ'shalah wa manâhij wa adawât manqûlah).

\footnotetext{
${ }^{5}$ Wahbah Zuhaili. Taghayyur Al-Ijtihâd, h. 7.

${ }^{6}$ Usman Husien. Al-Ahkâm al-Islâmiyah al-Müâsirah fî Ijtihâd al-Ulamâ al-Asiyin (Aceh: Arraniry Press, 2006), h. 19.

${ }^{7}$ Amin Abdullah. Antologi Studi Islam (Yogyakarta: DIP PTA, 2000), h. 277.

${ }^{8}$ Wahbah al-Zuhaily. Subul al-Istifâdah (Damaskus: Darl al-Maktabi, 2001), h. 5-6.

${ }^{9}$ Taha Abdurrahman. Tajdîd al-Manhaj fî Taqwîm al-Turâts (Maroko: Al-Markaz al-Tsaqafiy fî al-'Arabiy: al-Dar al-Baidla, 2007), h. 9-10.
} 
Dalam upaya revitalisasi turâst, hal utama yang perlu direkonsepsi adalah pemaknaan turâst itu sendiri, bahwa turâst adalah produk budaya (muntaj tsawâfy) yang bersifat relatif dan profan. Pemahaman klasik tentang sakralisasi turâst perlu didekonstruksi. Karena Islam (syariah) sendiri sebagai grand norms dari fikih tidak mengenal ortodoksi ekslusif, melainkan heterodoksi inklusif. ${ }^{10}$ Maka, syariah tidak hanya dibaca dengan univokalitas perspektif, tetapi multivokalitas perspektif. Esensinya turâst adalah hasil dari konstruksi sosial-budaya yang melingkupinya. Dialektika teks dan konteks semestinya tetap menjadi keyword dalam memaknai turâst.

Perubahan pemahaman terhadap konsepsi hukum Islam turâst tersebut salah satunya dihembuskan oleh Schacht yang meruntuhkan anggapan tradisional tentang hukum Islam. Schacht tidak lagi mengkaji

${ }^{10}$ Pemahaman keislaman yang inkulisif-terbuka dan menerima pemahaman toleransi merupakan cerminan fikih ramah terhadap dinamik kehidupan yang terus berkembang. Pemahaman tersebut dapat dilihat dalam beberapa karya yang dapatdijadikan rujukan seperti karya Agus Sunaryo. "Fikih Tasamuh: Membangun Kembali Wajah Islam yang Toleran." Akademika: Jurnal Pemikiran Islam 18, no. 2 (2013): h. 235-254. Agus Sunaryo. "Teologi Inklusif Nurcholis Madjid dan Pengaruhnya terhadap Fikih Lintas Agama di Indonesia." Al-Manahij: Jurnal Kajian Hukum Islam 6, no. 1 (2012): h. 1-14. Moch Anang Abidin, dan Fakultas Syari'ahh. "Kawin Beda Agama (Kajian Terhadap Buku Fikih Lintas Agama; Membangun Masyarakat Inklusif-Pluralis)." (2003). Abdullah Fikri. "Fikih Ramah Difabel." Inklusi 2, no. 1 (2015): h. 193-202. Moh Dahlan. "Norma Agama Nasrani dalam Paradigma Usul Fiqh Inklusif." Ijtihad: Jurnal Wacana Hukum Islam dan Kemanusiaan 14, no. 2 (2014): h. 189-209. Nasitotul Janah. "Implikasi Teologi Inklusif Nurcholish Madjid Terhadap Pemikiran Hukum Islam (Studi Kritis Terhadap Buku Fiqih Lintas Agama).” Phd Diss., Program Pascasarjana Universitas Muhammadiyah Yogyakarta, 2013. Andik Wahyun Muqoyyidin. "Membangun Kesadaran Inklusif-Multikultural untuk Deradikalisasi Pendidikan Islam." Jurnal Pendidikan Islam 2, no. 1 (2012). Edi Susanto. "Spiritualisasi Pendidikan Agama Islam: Menuju Keberagamaan Inklusif Pluralistik." Nuansa: Jurnal Penelitian Ilmu Sosial dan Keagamaan Islam 11, no. 2 (2014). Aries Musnandar. "Manajemen Inklusif dengan Prinsip Maqâshid al-Syarî́ah dalam Penghitungan Zakat dan Pajak." Ulul Albab 18, no. 2 (2017): h. 221. Fathorrahman. "Fikih Pluralisme dalam Perspektif Ulama NU." Asy-Syir'ah 49, no. 1 (2015): h. 101-119. Moh Dahlan. "Hermeneutika Hukum Islam Inklusif di Indonesia." Nuansa 8, no. 1 (2015). Nur Robi Wahidah. "Fiqh Toleransi dalam Pespektif Al-Qur'an Departemen Agama RI.” Maghza: Jurnal Ilmu Al-Qur'an dan Tafsir 1, no. 2 (2016): h. 99-114. Bakhtiar Pamungkas Rheza. "Studi Pemikiran KHh. Sahal Mahfudh Tentang Konsep Maslahah dan Implementasinya salam Fikih Sosial." PhD diss., STAIN Pekalongan, 2016. Saifudin Zuhri. "Menempatkan Nilainilai Fikih Islam dalam Proses Modernisasi dan Perubahan Sosial Studi tentang Teori al-Tufi Mazhab Hanbali." Ijtihad: Jurnal Wacana Hukum Islam dan Kemanusiaan 14, no. 2 (2014): h. 167-187. M. Zaidi Abdad. "Analisis dan Pemetaan Pemikiran Fikih Moderat di Timur Tengah dan Relasinya dengan Gerakan Fikih Formalis." Esensia: Jurnal Ilmu-Ilmu Ushuluddin 12, no. 1 (2016): h. 39-62. 
hukum Islam secara teologis dogmatis, melainkan lebih bersifat historis dan sosiologis. Schacht menyajikan hukum Islam bukan sebagai seperangkat norma yang diwahyukan, tetapi sebagai fenomena historis yang berhubungan erat dengan realitas sosial. Schacht menyimpulkan bahwa sebagian besar hukum Islam termasuk sumber-sumbernya, merupakan akibat dari sebuah proses perkembangan historis. ${ }^{11}$ Konsepsi Schacht tersebut membuka kesadaran umat Islam bahwa Islam (fikih) tidak hanya dipahami sebagai ajaran dogmatis yuristik, tetapi juga sarat dengan muatan historis-sosiologis. Dengan demikian, bisa dimaknai bahwa Islam (fikih) tidak hanya ditemukan dalam wahyu (revelation), tetapi juga dalam alam (nature).

Gagasan rekonstruksi fikih (tajdîd al-fiqh) dalam merespons modernitas memiliki signifikansi kajian yang positif. Secara umum, substansi dari diskursus tajdîd tersebut terfokus pada dua proyek. Pertama, pembaharuan normativitas fikih (tajdîd al-fikih al-Islâmî). Kedua, pembaharuan usul fikih sebagai metodologi ijtihad. Keduanya merupakan dua entitas yang berbeda, tetapi tidak bisa dipisahkan. ${ }^{12}$ Diskursus pembaruan ijtihad fikih akan memperjelas bargaining position fikih kontemporer dalam kajian fikih klasik. Menurut Yusuf al-Qarâdawi, fikih kontemporer tidak hanya sebagai solusi atas masalah-masalah fikih kontemporer, tetapi lebih sebagai bentuk review kritis konstruktif (I'adatun nadzar al-banna) terhadap fikih klasik baik dari segi muatan materi maupun metodologisnya. ${ }^{13}$

Dalam upaya tajdîd tersebut, al-Qarâdawi merekomendasikan tiga tipologi ijtihad kontemporer: ijtihâd intiqẩi (ijtihad selektif), ijtihâd insyẩi (ijtihad produktif) dan ijtihâd indimâjji (ijtihad integratif). ${ }^{14}$ Tidak hanya itu, upaya tajdîd juga harus dilakukan pada aspek metodologi dan pendekatannya. Dalam kajian usul fikih, metode istinbâth hukum dikategorikan dalam tiga metode: 1). Metode bayânî yakni metode

${ }^{11}$ Ali Masrur. Kontroversi Pembentukan Hukum Islam Kontribusi Joseph Schacht (Yogyakarta: UII Press, 2001), h. 16.

${ }_{12}$ Wahbah al-Zuhaily dan Jamaluddin Athiyah. Tajdìd al-Fiqh al-Islâmi (Damaskus: Dâr al-Fikir, 2000), h. 16-17.

${ }^{13}$ Al-Qarâdawi. al-Ijtihâd al-Mu'asir bain al-Inzibât wa al-Infirât (Kairo: Al-Maktab alIslami, 1998), h.16.

${ }^{14}$ Al-Qarâdawi. al-Ijtihâd al-Mu'asir bain al-Inzibât wa al-Infirât, h. 24. 
analisis berbasis gramatika linguistik. Dengan metode ini teks dianalisis berdasarkan kaidah-kaidah kebahasaan, hasilnya bersifat literalis-skriptualis; 2). Metode ta'lîlî (kausasi), yakni metode pencarian rasio-legis (illah) hukum yang terdapat dalam teks. Metode ini juga dikenal dengan metode qiyâsî (analogi-silogistik); 3). Metode istislâhî (teleologis), yakni pencarian makna pesan substantif (tujuan hukum/ultimate value) di balik teks. Metode ini juga dikenal dengan metode maqâshidî (purposive method). ${ }^{15}$

Dengan metode penemuan hukum di atas, paling tidak ada tiga pendekatan yang relevan. Pertama, pendekatan literalis-tekstualis berbasis pada gramatika linguistik (dalam istilah al-Jabiri dikenal dengan metode bayânî) dalam pengungkapan makna inferensial teks (mâ fî̀ annash). Sementara hukum Islam tidak lahir dari kondisi yang hampa (eksnihilo) dan diturunkan dalam kondisi yang hampa (innibilo) pula. Kedua, pendekatan sosio-historis (social-historical approaches), melihat pada konteks asbab nuzul (Alquran) dan asbâbul wurûd (al-Sunnah) untuk mengetahui makna preferensial teks (mâ haula al-nash). Ketiga, pendekatan filosofis-hermeneutis, digunakan untuk menemukan makna substansial teks (mâ warâa al-nash).

Pendekatan di atas tidak berdiri secara parsial, melainkan secara integral. Sebab notabene problematika fikih kontemporer masih bersifat aktual, tidak banyak dikaji dalam literatur fikih klasik, karena muatan materinya merupakan rekaman realitas klasik. Menurut Syamsul Anwar, fikih klasik punya banyak kelemahan sehingga tidak cukup memadai untuk menjawab problematika kontemporer. ${ }^{16}$ Karenanya, mujtahid harus menggunakan berbagai pendekatan integratif saintifik dan multi perspektif. Dengan demikian, hukum harus dikonsepsikan sebagai ius constituendum (law as what ought to be) atau fikih yang seharusnya, yakni fikih yang sesuai ruh syariat, bukan hukum sebagai ius constitutum (law as what it's in the book) atau fikih apa adanya. Di sinilah letak ruang ijtihad (majal al-ijtihâd) fikih responsif.

${ }^{15}$ Asymuni Abdurrahman. Manhaj Tarjih Muhammadiyah (Yogyakarta: Pustaka Pelajar, 2003), h. 113-116.

${ }^{16}$ Syamsul Anwar. Pengembangan Metode Penelitian Hukum, dalam Profetika 4, Jurnal Magister Studi Islam UMS Surakarta, 2002. 
Dampaknya, mujtahid akademik harus mempunyai sikap kritis dan responsif terhadap realitas modern dengan membuat formulasi baru materi fikih dan konstruksi baru metodologi ijtihad hukum Islam dengan pendekatan integratif-multidisipliner. Fikih responsif harus memadukan muatan sui-generis (tekstual) dan kum-empiris (kontekstual) dengan metode eklektik antara induktif-deduktif. Realitas modern (modernitas) harus diposisikan sebagai teks budaya yang bersifat partikular. Sedangkan teks sumber (Alquran dan al-Sunnah) diposisikan sebagai teks budaya yang bersifat general. Keduanya (antara teks partikular dan teks general) didialektikakan secara eklektik guna menemukan makna filosofis (philosophical meaning), karena keduanya bersifat komplementer.

Berikut ilustrasi tentang urgensi peran ilmu-ilmu modern dalam mekanisme ijtihad fikih kontemporer.

Bagan 1: Kontribusi ilmu-ilmu modern ijtihad fikih

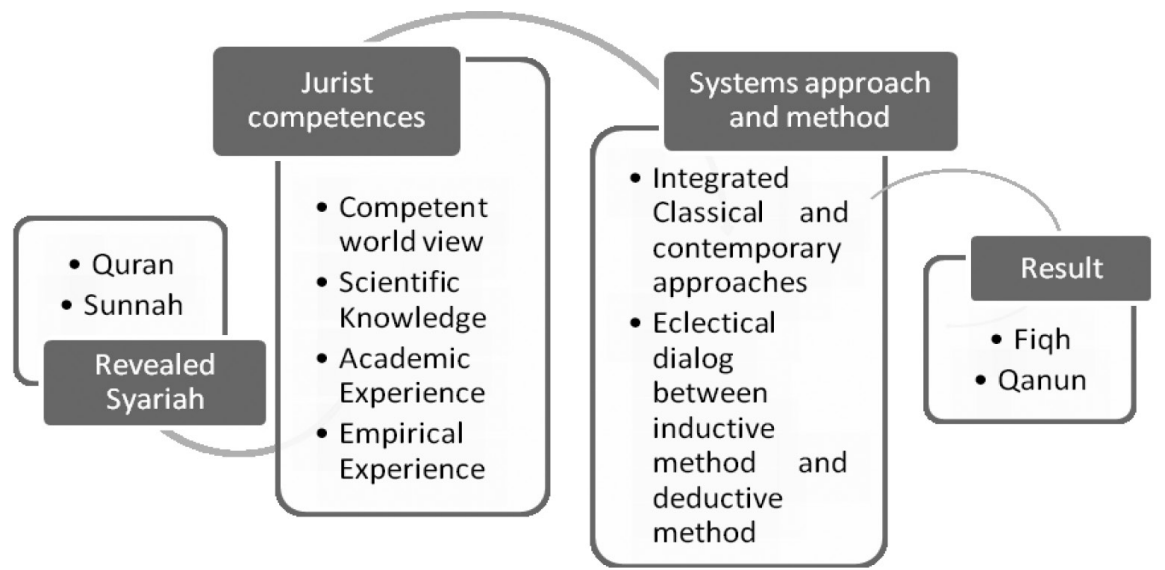

\section{Filosofi Fikih Reponsif}

Gagasan fikih responsif esensinya adalah bentuk reinterpretasi mujtahid terhadap teks (nash) sebagai produk budaya (muntaj tsaqafíy) untuk merespons modernitas dalam istimbat hukum (fikih). Term "responsif" di atas, penulis fahami dari tipologi hokum yang digagas oleh Philippe Nonet dan Philip Shelznick dalam bukunya Hukum Responsif (terj) yang membaginya dalam tiga tipe: hukum represif, hukum otonom, 
hukum responsif. Dalam definisinya, hukum responsif adalah hukum yang dibuat untuk merespons terhadap fenomena, tindakan, perilaku atau peristiwa hukum yang menjadikan keadilan substantif sebagai orientasi tujuan hukum (dalam terminologi keislaman disebut maqâshid syarîah). ${ }^{17}$ Dalam konteks fikih, dikatakan demikian karena kenyataannya ketika Alquran diturunkan itu tidak terlepas dari konteks sosio-historisnya. Perekaman sejarah yang dilakukan dalam bentuk ayat-ayat itu adalah bentuk "dialogisasi" atau dialektika antara teks dan realitas, antara teks dan kebudayaan. Jika tidak ada reinterpretasi dan tajdîd, maka fikih akan kehilangan momentum historis dan tidak mampu menjawab tantangan modern.

Historisitas tadrîj al-ayat di atas menegaskan bahwa pemahaman agama tidak menghendaki adanya "finalisasi" gagasan dalam memahami makna agama. Dengan kata lain, bisa disebut juga "unfinished religion understanding”. Aspek lokalitas dan kontekstualisasinya perlu diapresiasi dalam menghadirkan agama yang dinamis, sehingga pemaknaan agama pun selalu dinamis. Hal ini karena agama terkait dengan ragam kontruksi dan polaritas penafsiran manusia. Ketika konteksnya berubah, maka pemahaman hukumnya pun bisa berubah (al-ahkâm walidatul hâjah). Adanya klaim universalitas dan otentisitas (Islam) hanya pada sisi nilainilai filosofisnya saja, tidak pada sisi historisnya. Sebab, sisi historis adalah sisi partikular dalam agama. Dalam istilah al-Qarâdawi, sisi filosofisnya disebut "al-stâbit" (sakral/statis). Sedangkan sisi historisnya disebut "almutathawwir" (profan/dinamis). Dalam fikih, sisi filosofis berupa nilainilai prinsipil (al-mabâdi' al-asâsiyah) dan maqâshid syarîah yang bersifat qath'i. Sementara lainnya bersifat $d z a n n i$ (multi interpretatif). ${ }^{18}$

Kini, pemahaman agama harus terus berproses untuk menemukan makna subtantif yang terkandung dalam teks dengan melihat pada perubahan realitas yang sangat dinamis (taghayyur al-ahkâm bi taghayyur

17 Philippe Nonet, Philip Shelznick and Robert Kagan. Law and Society in Transition: Toward Responsive Law (Routledge, 2017), h. 18-19.

${ }^{18}$ Pemahaman qathi dan dzanni dalam cakrawala hukum Islam bisa dilihat dalam karya Subhan. "Klasifikasi Ayat-ayat Hukum (dari Segi Qathi dan Zhanni)." Mazahib 12, no. 2 (2013). Ratu Haika. "Konsep Qathi dan Zhanni dalam Hukum Kewarisan Islam.” Mazahib 15, no. 2 (2016): h. 182-195. 
al-azminah wa al-amkinah). Maka, sangat mungkin agama mampu berdialog dengan dinamika perubahan zaman. ${ }^{19}$ Pembacaan kritis terhadap agama dengan "merevitalisasi” tradisi (turâts) akan mampu merespon tantangan modernitas. Agama dan modernitas bukanlah dua kutub yang selalu berlawanan, tetapi ada ruang dialog dan kritik dalam menyikapi hadirnya modernitas. Oleh karena itu, agama tidak boleh "mati” dan bahkan harus hadir sebagai problems solver di tengah modernitas global.

\section{Modernisasi Fikih: Integrasi Fikih dan Sains}

Istilah modern secara bahasa berarti baru, kekinian, akhir, up to date atau semacamnya. Bisa dikatakan sebagai lawan dari lama, kolot atau semacamnya. ${ }^{20}$ Modernisasi memang sangat luas artinya, mencakup proses memperoleh citra (images) baru seperti citra tentang arah perubahan atau citra tentang kemungkinan perkembangan. ${ }^{21}$ Batasan-batasan modernisasi seringkali hanya ditekankan pada aspek-aspek perubahan di bidang teknologi dan ekonomi. Akan tetapi, sebagaimana dikemukakan oleh Manfred Halpern, revolusi modernisasi sebenarnya melibatkan transformasi semua sistem yang berlaku sebelumnya dalam masyarakat, baik sistem politik, sosial, ekonomi, intelektual, keagamaan maupun psikologi. ${ }^{22}$

Perubahan itu juga terjadi dalam bidang pemikiran (intelektual). Sebagai contoh bahwa abad modern ditandai oleh kemenangan supremasi rasionalisme, empirisme, positivisme dari dogmatisme agama pada abad ke-

${ }^{19}$ Hukum Islam sejatinya bisa "berdamai" dengan sosial, karena dalam kehidupan sosial, perubahan menjadi keniscayaan sejarah. Dalam hal ini bisa dilihat pada karya Zulham Wahyunadi, dan Raihanah HJ Azahari. "Perubahan Sosial dan Kaitannya dengan Pembagian Harta Warisan dalam Perspektif Hukum Islam." Jurnal Ilmiah Islam Futura 14, no. 2 (2015): h. 166-189. Pradana Boy ZTF. Fikih Jalan Ttengah: Dialektika Hukum Islam dan Masalah-masalah Masyarakat Modern. (Jakarta: PT Grafindo Media Pratama, 2008). Mujiyono Abdillah. Dialektika Hukum Islam \& Perubahan Sosial: Sebuah Refleksi Sosiologis Atas Pemikiran Ibn Qayyim al-Jauziyyah. (Surakarta: Muhammadiyah University Press, 2003). Badri Khaeruman. "Al-Qaradawi dan Orientasi Pemikiran Hukum Islam untuk Menjawab Tuntutan Perubahan Sosial." Wawasan: Jurnal Ilmiah Agama dan Sosial Budaya 1, no. 2 (2016): h. 227-238.

${ }^{20}$ Ahmad Qodri Abdillah Azizy. Melawan Globalisasi : Reinterpretasi Ajaran Islam: Persiapan SDM dan Terciptanya Masyarakat Madani, Cet. 1 (Yogyakarta: Pustaka Pelajar, 2003), h. 28.

${ }^{21}$ Robert H. Lauer. Perspectives on Social Change (Allyn and Bacon, 1982), h. 414.

${ }^{22}$ Manfred Halpern. 'Toward Further Modernization of the Study of New Nations', ed. by Karl W. Deutsch and others, World Politics, 17.1 (1964), h. 157-181. 
17. Metode ilmiah yang berwatak rasional dan empiris telah mengantarkan kehidupan manusia pada suasana modernisme. ${ }^{23}$ Jadi masyarakat modern secara intelektual adalah masyarakat rasional, didasarkan pada ilmu dan teknologi yang logis dan empiris.

Akan tetapi, yang menjadi perdebatan di antara beberapa kelompok di atas bukanlah tentang pokok-pokok ajaran agama itu sendiri (great tradition), melainkan bagaimana memanifestasikan ajaran Islam itu di dalam sistem kehidupan sosial (little tradition). ${ }^{24}$ Sebab, perubahan masyarakat dalam berbagai aspeknya-baik ekonomi, politik, sosial, budaya dan sebagainya - harus direspon oleh hukum Islam secara positif. Respon positif yang dimaksud berupa implementasi dari peran hukum Islam di tengah kehidupan masyarakat, sebagai pengendalian sosial (social controlling), pemberdayaan sosial (social engineering) dan kesejahteraan sosial (social welfare). ${ }^{25}$ Dengan fungsi-fungsi ini, diharapkan hukum Islam tidak mengalami krisis dan inefektivitas hukum di tengah kehidupan masyarakat yang makin kompleks.

Fikih sebagai norma etik adalah produk pemikiran ilmiah kaum mujtahid. Sebagai hasil dari analisis ilmiah, fikih tentu tidak bisa dilepaskan dari cara berfikir logis dan empiris. Karenanya, dalam kajian fikih semua bidang keilmuan memiliki peran yang signifikan dalam upaya induktifikasi maupun deduktifikasi temuan hukum. Dalam konteks ini barangkali perlu sinergisitas sains, filsafat dan agama (teks). Hal ini mutlak diperlukan untuk membangun fikih responsif di era modern, khususnya dalam membuat rumusan baru usul fikih sebagai metodologi fikih. Integrasi ilmu (sains) dan agama (teks) tidak dapat dipungkiri lagi keberadaannya sebagai metode indimâji (dalam bahasa al-Qarâdawi) untuk menjawab problematika hukum modern. Sebab, berpaku pada analisis tekstual-linguistik semata tidak cukup memadahi untuk menganalisa fenomena hukum kekinian.

${ }^{23}$ F.B. Burnhan. Postmodernism Theology (Sanfrancisco: Heper \& Row Publisher, 1989), h. 19.

${ }^{24}$ Andrew Rippin and Associate Professor of Religious Studies Andrew Rippin, Muslims: Their Religious Beliefs and Practices (Routledge, 2014), h. 19.

${ }^{25}$ M. Abdillah. Dialektika Hukum Islam dan Perubahan Sosial. (Surakarta: UMS Press, 2003), h. 2. 
Dalam karyanya, Maqâshid Syarîah (editor Abdul Jabbar Rifảah), Abdul Hadi al-Fadli merekomendasikan dialektika dua pendekatan: tharîah bunyâniyah (pendekatan struktural linguistik) dan tharîqah biìyah (pendekatan sosio-historis kontekstual). ${ }^{26}$ Pendekatan dialektik-integratif yang dimaksud tidak hanya melibatkan ilmu-ilmu ke-Islam-an, tetapi juga ilmu-ilmu lain yang relevan dan turut membantu memperjelas hadirnya fikih baru ( fiqh jadîd), seperti ilmu-ilmu humaniora, ilmu-ilmu eksakta dan sebagainya. Lain dari pada itu, agar fikih tidak hanya ada dalam ruang privat, maka perlu adanya taqnîn (legislasi) menjadi sebuah undangundang sehingga fikih lahir dalam ruang publik. Konsep taqnîn syarîah (legislasi syariah) di sini tidak berarti menjadikan Alquran dan al-Sunnah sebagai undang-undang formil (seperti konstitusi), tetapi melakukan resepsi (receptio) nilai-nilai substantif syariah ke dalam undang-undang.

Dalam rangka merumuskan fikih responsif, kiranya perlu memperhatikan beberapa konsep berikut. Pertama, obyektifikasi. Fikih tidak lagi berdasar pada tirani ideologi mazhab, tetapi lebih dipahami sebagai respon atas dinamika realitas dan problematika umat. Untuk itu, perlu pendekatan komparatif dalam merumuskan fikih. Materi fikih pun dalam hal ini harus memortret realitas (kekinian) atau disebut fiqh waqîi i, bukan fiqh khayâli (atau disebut juga fiqh iftirâdhî) fikih yang absurd dan tidak realistik. Kedua, komplementasi. Fikih sebagai produk penafsiran mujtahid tidak harus selalu bersifat positivistik, sehingga terkesan bersikap antagonis dengan realitas. Fikih dan realitas harus saling melengkapi satu sama lain. Fikih tanpa realitas "tidak ada"(mafqûd), realitas tanpa fikih tidak etis, karena fikih hakikatnya adalah norma etik (ethic norm). Ketiga, induktifikasi. Fikih selama ini selalu dihasilkan dari metode berfikir deduktif, berangkat dari teks dalam membaca realitas. Hasilnya tidak jarang menghakimi (untuk tidak menyebut menvonis) realitas secara hitam putih. Padahal sudah dimaklumi bahwa teks terbatas, sedangkan realitas tidak terbatas. Bagaimana "sesuatu yang terbatas" mampu menjawab "sesuatu yang tak terbatas". Di sinilah problemnya. Karena itu, induktifikasi, membaca realitas obyektif untuk dicarikan nilai etik dan

${ }^{26}$ Abdul Jabbar Rifa'ah. Maqâshid Syarîah, (Beirut: Darl Fikr, 2002), h. 217. 
filosofisnya dalam teks agar memiliki legal standing. Keempat, verifikasi. Fikih sebagai produk budaya tentu tidak bersifat final dan statis. Maka, sakralisasi fikih adalah sikap ironis dan bertentangan dengan sifat murû̉ah (elastisitas) Islam. Fikih idealnya harus selalu diuji, baik secara teoritis maupun metodologis. Jangan sampai lahir fikih yang ahistoris terhadap realitas sosial dan budaya yang ada dan membawa muatan ideologis sehingga fikih tidak lagi responsif dan humanis.

Di samping itu, perlu juga kiranya melakukan perubahan paradigm (shifting paradigm), dari paradigma literalis menuju paradigma filosofis. ${ }^{27}$ Pertama, paradigma literalis. Paradigma ini menjadikan teks dibaca apa adanya secara skriptualis (dzâhiriyat al-nash) berdasar pada kaidah-kaidah linguistik. Sehingga hasil ijtihadnya bersifat positivistik. Kedua, paradigma kausasif, paradigma ini mencari hukum melalui ada tidaknya 'illat (legal reasoning) di balik teks. Metode yang digunakan adalah qiyas, sehingga disebut juga ijtihâd qiyâsî̀ (metode ta'lîlî̀). Hasil dari ijtihad kausasif ini masih bersifat normatif. Paradigma ini berlangsung selama kurang lebih 6 abad. ${ }^{28}$ Enam abad kemudian, paradigma ini mulai bergeser ke paradigma teleologis-filosofis yaitu paradigma yang menjadikan teks tidak hanya dibaca secara skriptualis maupun kausasif (berdasar 'illat/rasio legis), tapi mengacu kepada prioritas nilai-nilai filosofis (ground norms/ultimate values). Paradigma ini mulai diwacanakan oleh Imâm al-Juwaini, alGazâli, al-Izz (Izzuddin bin Abd Salam), Ibn Taimiyah, Ibn al-Qayyim al-Jauziyah hingga mencapai puncaknya pada masa al-Syatibi pada abad ke-8H/14M. ${ }^{29}$ Paradigma ketiga ini disebut juga paradigma utilitarianis (ijtihâd istishlâhîlijtihâd maqâshidî).

${ }^{27}$ Asjmuni Abdurrahman. Manhaj Tarjih Muhammadiyah: Metodologi dan Aplikasi (Jakarta: Pustaka Pelajar, 2002), h. 91-92.

${ }^{28}$ Dalam sejarah, Al-Risâlah karya as-Syafi'i adalah buku pertama tentang sistematika kajian usul fikih. Walau harus diakui ulama sebelumnya telah banyak melahirkan fikih. Akan tetapi metode yang digunakan belum tersusun secara sistematik seperti karya al-Syafi'ie. Al-Risâlah yang penulisannya bercorak teologis-deduktif itu kemudian diikuti oleh para ahli usul mazhab Mutakallimûn (Syaf'iyah, Malikiyah, Hanabilah dan Mu'tazilah). Sementara itu mazhab fukaha (ulama Hanafiyah) memiliki cara penulisan tersendiri yang bercorak induktif-analitis. Baik AlRisâlah, buku-buku usul mazhab Mutakallimûn maupun mazhab Hanafiyah memiliki kesamaan paradigma, yaitu paradigma literalistik dalam arti begitu dominannya pembahasan tentang text. Adnan Moh. Umam. Al-Tajdîd Fî al-Fikr Islâmi (Saudi Arabia: Dar Ibn Jauzi, 1424), h.143.

${ }^{29}$ Moh. Umam. Al-Tajdîd Fî al-Fikr Islâmi, h. 147. 
Untuk itu, mujtahid kontemporer harus memiliki tiga dimensi kesadaran yakni kesadaran historis (al-wa'yu al-târikhiy), kesadaran teoritis (al-wa'yu al-nadzâriy) dan kesadaran realistis-praktis (al-wa'yu al-'amaliy). ${ }^{30}$ Dengan kesadaran historis, seorang mujtahid harus memahami substansi dari kronologi lahirnya teks dan dapat menangkap pesan di balik teks. Kesadaran ini mengantarkan mujtahid pada pentingnya ilmu sosiologi hukum dan sejarah hukum sebagai pendekatan. Karena hakikatnya hukum lahir dipengaruhi oleh historisitas dan konstruksi sosial masyarakat. Sedangkan kesadaran teoritis menyadarkan mujtahid untuk memiliki keilmuan yang multidisiplin, bukan monodisiplin. Karena teks-teks hukum tidak dapat dipisahkan dari teks-teks lainnya seperti teks sosial, teks budaya dan sebagainya. Dengan demikian, mujtahid kontemporer hendaknya mampu mendialektikakan pendekatan klasik (clasiccal approaches) dan pendekatan kontemporer (contemporary approaches) dengan berbasis maqâsid hukum. Pada gilirannya kesadaran kontekstual pun harus menjadi acuan optik mujtahid agar tidak terjadi kekosongan hukum. Sebab teks sendiri tak ubahnya hasil rekam konteks masa lalu yang harus dibaca untuk konteks sekarang.

Dengan pendekatan dialektika deduktif-induktif (dalam bahasa alQarâdawi disebut indimâjiyah bain al-intiqâai wa al-insyẩi), maka produk ijtihad (fikih) akan mampu menjawab problematika hukum (qadaya alahkâm) yang terjadi di tengah-tengah masyarakat. Tanpa pendekatan ini, maka hukum akan "berbicara dengan dirinya sendiri" (law talks by its self) dan tidak responsif terhadap realitas. Walhasil, idealnya fikih adalah hasil pemikiran dialektik antara teks dan konteks atau antara nas dan realitas (al-indimâj bain al-nas wa al-wâqi) seperti digambarkan dalam bagan berikut:

${ }^{30}$ Hasan Hanafi. Min al-Nash ila al-Wâqi' (Kairo: Markaz Al-Kitab, 2005), h. 55. 


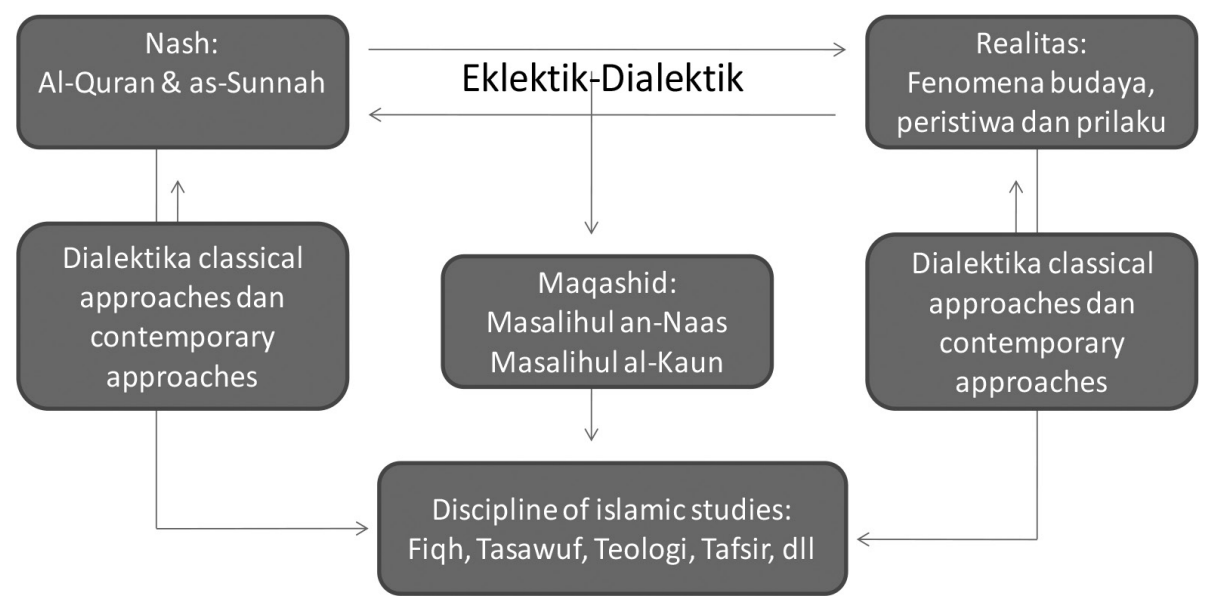

Gambar di atas menjelaskan: pertama, nas dan realitas dibaca dengan pendekatan eklektik-dialektik antara classical approaches dan contemporary appoaches yang berorientasi pada maqâshid syarîah (maqâshid al-nâs dan maqâshid al-kaun); kedua, integrasi nas dan realitas menjadi landasan filosofis dari setiap disiplin keilmuan Islam (fikih, tafsir, tasawuf dan teologi); ketiga, dilakukan philosophical clarification berbasis maqâshid, sehingga mampu melahirkan produk pemikiran atau pengetahuan baru (baca: fikih) yang memiliki karakteristik humanis-ekologis, responsifadaptif dan inklusif-progresif sesuai tuntutan spirit zaman.

Cita-cita ideal di atas akan terwujud dalam konteks fikih kontemporer, manakala mujtahid membaca dan memahami teks (nas) secara komprehensif, mulai dari: 1). Mantûq al-nash (pengertian yang ditunjuk oleh suatu pernyataan hukum yang bersifat eksplisit); 2). Mafhîm al-nash (pengertian yang ditunjuk oleh suatu pernyataan hukum yang bersifat implisit); 3). Ma'qûl al-nash (perluasan makna implisit dengan metode kausasi); 4). Rûh al-nash (substansi makna teks yang diperoleh melalui metode konformitas teleologis-filosofis atau metode maqâshid). ${ }^{31}$

Beberapa contoh hasil ijtihad kontemporer, misalnya: 1). Pejabat publik (seperti menteri Negara dan sebagainya) dari kalangan Non-

${ }^{31}$ Syamsul Anwar. Argumentum A Fortiori dalam Metode Penemuan Hukum Islam (Yogyakarta, Fakultas Syariah, UIN Sunan Kalijaga, 2007), h. 155-157. 
Muslim bagi negara yang berasaskan Islam. Lebih-lebih jika mayoritas warga negaranya non-muslim seperti di Sudan. Menurut Abû Ya’la dan Al-Mawardi sebagaimana dikutip al-Qarâdawi, seorang pemimpin Negara tidak disyaratkan muslim, tetapi harus memiliki integritas dan profesionalitas di bidangnya. Dalam hal ini, al-Qarâdawi mencontohkan Faris al-Khuri seorang non-muslim yang diangkat menjadi menteri di Suriah atas dukungan komunitas muslim karena kompetensi keilmuan dan kapabilitas skill yang dimilikinya. Kasus ini adalah kasus kontemporer yang belum muncul dalam fikih klasik. Padahal relasi muslim dan nonmuslim saat ini tidak bisa dipungkiri realitasnya; ${ }^{32} 2$ ). Perlindungan hak-hak kaum minoritas (ahl al-dzimmah) dalam politik Islam. Hak perlindungan warga Negara non-muslim di Negara Islam menurut alQarâdawi dikategorikan sebagai ahl al-dzimmah (orang non muslim yang berdamai dengan pemerintah Islam). Mereka mendapatkan hak yang sama dengan masyarakat muslim di Negara Islam, karena kata dzimmah bisa dimaknai wathan (negeri). Artinya abl al-dzimmah sama dengan ahl al-wathan (orang muslim pribumi). Karena itu sebagai warga Negara mereka mempunyai hak yang sama untuk mendapat perlindungan dari pemerintah Islam. Dalam istilah al-Qarâdawi, lahum mâ lanâ wa alaihim mâ alaina (hak mereka adalah hak kita juga dan kewajiban mereka adalah kewajiban kita juga); 3). Emansipasi wanita. ${ }^{33}$ Menurut al-Qarâdawi

${ }^{32}$ Beberapa tulisan yang membahas kepemimpinan non muslim bisa dilihat pada karya $\mathrm{H}$. M. Syarif, dan Mujar Ibnu. "Memilih Presiden Non-Muslim di Negara Muslim dalam Perspektif Hukum Islam." Jurnal Konstitusi 1, no. 1 (2008). Mary Silvita. "Presiden Non-Muslim dalam Komunitas Masyarakat Muslim.” Islamica: Jurnal Studi Keislaman 7, no. 1 (2012): h. 44-60. Muhammad Suryadinata. "Kepemimpinan Non-Muslim dalam al-Qur'ân: Analisis Terhadap Penafsiran FPI Mengenai Ayat Pemimpin Non-Muslim.” Ilmu Ushuluddin 2, no. 3 (2016): h. 241-250.

${ }^{33}$ Pemahaman gender berorientasi kepada emasipasi wanita menjadi isu hangat dan terus bergulir dalam dunia muslim. Tulisan yang membahas hal tersebut dapat dilhat pada karya Erasiah. "Tokoh Emansipasi Wanita Islam di Mesir pada Abad Ke 19 M." Kafaah: Journal of Gender Studies 4, no. 2 (2014): h. 202-218. Nur Lailatul Musyafa'ah. "Pemikiran Fikih Wanita Qasim Amin.” Jurnal JS GI 4, no. 01: 2087-983. Masnun Tahir. "Hak-hak Perempuan dalam Hukum Keluarga Syiria dan Tunisia." Al-Mawarid 18 (2008). Abdullah Yusof, Rahimin Abd Rahim, Nor Adina Abdul Kadir, dan Nor Hayati Md Dahlal. "Konsep Feminisme Islam di dalam Film Ketika Cinta Bertasbih." Journal of Al-Tamaddun 5 (2010): h. 131-147. Rahimin Affandi Abd Rahim, Paizah Ismail, dan Norhayati Mohd Dahlal. "Reformasi Undang-Undang Keluarga Islam di Malaysia: Satu Analisis Terhadap Gagasan Konsep Fiqh Semasa.” International Journal of Mechanical and Materials Engineering (1970). Nur Lailatul Musyafa'ah. "Studi Hukum 
seorang perempuan boleh mengikuti kontestasi politik untuk menjadi pejabat publik (pemimpin Negara dan jabatan lainnya) selama memiliki kompetensi keilmuan di bidangnya. Al-Qarâdawi menganalogikannya dengan sosok Ratu Balqis, penguasa negeri Saba' yang diceritakan dalam Alquran. Pendapatnya ini menyalahi pendapat jumhur ulama klasik yang melarang perempuan menjadi pemimpin.

\section{Penutup}

Kesadaran bahwa Islam is compatible with modernity harus selalu ada dalam kosmologi berpikir mujtahid akademik kontemporer, agar visi Islam rahmatan lil 'alamin benar-benar dapat diimplementasikan. Hal ini juga diperkuat oleh sifat elastisitas Islam sendiri yang relevan dan applicable untuk diterapkan dalam tempus dan locus manapun. Dua karakteristik universalitas (syumûliyah) dan elastisitas (murûnah) Islam ini yang membuat Islam tetap eksis dan responsif terhadap perkembangan zaman hingga kini.

Untuk mencapai itu, hal yang paling urgen adalah perubahan paradigm berpikir kaum agamawan (mujtahid) dalam memahami agama (Islam dalam arti luas dan fikih dalam arti sempit). Sikap moderat dan inklusif sangat diperlukan dalam rangka living law bagi komunitas muslim sendiri dan upaya peace building and living together bagi komunitas lain. Pada akhirnya, apa yang dicita-citakan sebagai masyarakat madani (civilized society) dalam Islam akan terealisir.

Paradigma berpikir moderat dan inklusif harus dibangun dari dialektika inferensi tekstual (nas) dan konstruksi kontekstual (sosiokultural) dengan berdasar pada nilai-nilai etik dan filosofis sebagai ajaran substantif Islam. Oleh sebab itu, methodological approaches mutlak digunakan untuk tidak terjebak dalam hegemoni mazhab dan taqlidisme ideologis. Sebab idealnya seorang mujtahid akademik tidak bersikap sektarian, tetapi netral.

Perkawinan Islam di Indonesia Perspektif Gender.” Al-Hukama' 4, no. 2 (2014): h. 409-430. Rustam Dahar Karnadi Apollo Harahap. "Kesetaraan Laki-laki dan Perempuan dalam Hukum Perkawinan Islam." Sawwa: Jurnal Studi Gender 8, no. 2 (2013): h. 361-386. Ahmad Izzuddin. "Peran Sayyidah 'Aisyah dalam Pembentukan Hukum Islam Berwawasan Gender." Egalita (2012). 


\section{Pustaka Acuan}

Abdurrahman, A. Manhaj Tarjih Muhammadiyah. Yogyakarta: Pustaka Pelajar, 2003.

Abdillah, M. Dialektika Hokum Isam Dan Perubahan Social. Surakarta: UMS Press, 2003.

Abdullah, A. Teori Konformitas dalam Metode Penemuan Hukum Islam al-Gazzali, dalam Antologi Studi Islam. Yogyakarta: DIP PTA, 2000. Abdurrahman, T. Tajdîd al-Manhaj fi Taqwîm al-Turâts. Maroko: alMarkaz al-Tsaqafiy fî al-'Arabiy; al-Dar al-Baidla, 2007.

Abidin, Moch Anang, dan Fakultas Syari'ah. "Kawin Beda Agama (Kajian Terhadap Buku Fikih Lintas Agama; Membangun Masyarakat Inklusif-Pluralis).” (2003).

Abdad, M. Zaidi. "Analisis dan Pemetaan Pemikiran Fikih Moderat di Timur Tengah dan Relasinya dengan Gerakan Fikih Formalis." Esensia: Jurnal Ilmu-Ilmu Ushuluddin 12, no. 1 (2016): 39-62.

Abdillah, Mujiyono. Dialektika Hukum Islam \& Perubahan Sosial: Sebuah Refleksi Sosiologis atas Pemikiran Ibn Qayyim al-Jauziyyah. Surakarta: Muhammadiyah University Press, 2003.

Abror, Robby Habiba. "Identitas Islamis dalam Tegangan dan Negosiasi Antara Dogma dan Modernitas: Resepsi Komunitas Salafi di Yogyakarta Terhadap Fenomena Ghibah Infotainment." PhD diss., Universitas Gadjah Mada, 2014.

Anwar, S. Argumentum A Fortiori dalam Metode Penemuan Hukum Islam”, dalam Studi Hukum Islam. Repository. UIN Sunan Kalijaga Fakultas Syariah, 2007.

Anwar, S. Pengembangan Metode Penelitian Hukum. Profetika: Magister Studi Islam UMS Surakarta, 2002.

Anis, Muhammad. “Spiritualitas di Tengah Modernitas Perkotaan.” Jurnal Bayan 2, no. 4 (2013).

Arifinsyah. "Respons Islam dan Kristen Terhadap Modernitas.” Journal Analytica Islamica 3, no. 2 (2014): 274-295.

Asmaya, Enung. "Modernitas dan Tantangannya Terhadap Pelaksanaan Dakwah." Komunika: Jurnal Dakwah dan Komunikasi 3, no. 1 (2009): 46-62.

Azizy, A. Q. Melawan Globalisasi. Yogyakarta: Pustaka Pelajar, 12003. 
Basri, Mohammad Hasan. "Ritual Ya Qowiyu: Pergulatan Makna Modernitas, Agama, Budaya Lokal dan Kapitalisme." El-Harakah 11, no. 2 (2009).

Burnhan, F.B. (1989). Postmodernism Theology. Sanfrancisco: Heper \& Row Publisher.Rifảah, A. J. Maqâshid Syariah. Bayrut: Darl Fikr, 2002.

Daya, Burhanuddin. Agama Dialogis: Merenda Dialektika Idealita dan Realita Hubungan Antar Agama. Mataram-Minang Lintas Budaya, 2004.

Dahlan, Moh. "Hermeneutika Hukum Islam Inklusif di Indonesia." Nuansa 8, no. 1 (2015).

Erasiah, Erasiah. "Tokoh Emansipasi Wanita Islam di Mesir pada Abad Ke 19 M." Kafaah: Journal of Gender Studies 4, no. 2 (2014): 202-218. Fadlan, Andi. "Sains dan Agama Dialog Untuk Saling Menguatkan." Progres 4, no. 1 (2016).

Fathorrahman, Fathorrahman. "Fikih Pluralisme dalam Perspektif Ulama NU.” Asy-Syir'ah 49, no. 1 (2015): 101-119.

Fikri, Abdullah. "Fikih Ramah Difabel." Inklusi 2, no. 1 (2015): 193-202. Dahlan, Moh. "Norma Agama Nasrani dalam Paradigma Usul Fiqh Inklusif." Ijtihad: Jurnal Wacana Hukum Islam dan Kemanusiaan 14, no. 2 (2014): 189-209.

Gordon, S. The History and Philosophy of Social Science. New York: Routledge, 1991.

Haika, Ratu. "Konsep Qath'i dan Zhanni dalam Hukum Kewarisan Islam." Mazahib 15, no. 2 (2016): 182-195.

Halpen, M., Deutch, K. W., Foltz, W. J. and Mair, L. (1964). Toward Further Modernization of the Study of New Nations. World Politics, 17 (1). 157-181.

Hamdi, Ahmad Zainul. "Agama di Tengah Jaring-jaring Dunia Modern." Religió: Jurnal Studi Agama-agama 3, no. 2 (2013).

Harahap, Rustam Dahar Karnadi Apollo. "Kesetaraan Laki-laki dan Perempuan dalam Hukum Perkawinan Islam." Sawwa: Jurnal Studi Gender 8, no. 2 (2013): 361-386.

Hanafi, H. Min al-Nash ilâ al-Wâqi.' Kairo: Markaz Al-Kitab, 2005.

Husien, U. Al-Ahkâm al-Islâmiyah al-Muâsirah Fi Ijtihâd al-Ulamâ alAsiyin. Aceh:Arraniry Press, 2006. 
Ihsan, Muhammad. "Pendidikan Islam dan Modernitas di Timur Tengah: Studi Kasus Mesir." Hunafa: Jurnal Studia Islamika 4, no. 2 (2007): 129-142.

Irwansyah, Irwansyah. "Modernisme, Fundamentalisme Agama dan Terorisme." Miqot: Jurnal Ilmu-ilmu Keislaman 33, no. 2 (2009).

Izzuddin, Ahmad. "Peran Sayyidah 'Aisyah dalam Pembentukan Hukum Islam Berwawasan Gender.” Egalita(2012).

Janah, Nasitotul. "Implikasi Teologi Inklusif Nurcholish Madjid Terhadap Pemikiran Hukum Islam (Studi Kritis Terhadap Buku Fiqih Lintas Agama).” Phd Diss., Program Pascasarjana Universitas Muhammadiyah Yogyakarta, 2013.

Khaeruman, Badri. "Al-Qaradawi dan Orientasi Pemikiran Hukum Islam untuk Menjawab Tuntutan Perubahan Sosial." Wawasan: Jurnal Ilmiah Agama dan Sosial Budaya 1, no. 2 (2016): 227-238.

Kusnadiningrat. Sejarah Teori Hukum Islam. Jakarta: Grafindo, 2000.

Lauer, R. H. Perspectives on Social Change. Allyn and Bacon., 1982.

Luthfi, Asma. "Aji Modereng Dialektika Agama dan Modernitas pada Masyarakat Bugis di Pedesaan." Cultural Studies di PTAI: Teori dan Praktik. Bunga Rampai 1, no. 1 (2016): 1-6.

Minhaji, A. Kontroversi Pembentukan Hukum Islam Kontribusi Joseph Schacht. Yogyakarta: UII Press, 2001.

Musyrifah, A. Al-Qadlâ Fi al-Islâm. Syirkah Syarqil Ausath, 1966.

Mustofa, M. Lutfi. "Pembaruan Pemikiran Islam Indonesia: Negosiasi Intelektual Muslim dengan Modernitas.” Ulul Albab Jurnal Studi Islam (2013).

Musyafa'ah, Nur Lailatul. "Studi Hukum Perkawinan Islam di Indonesia Perspektif Gender." Al-Hukama’ 4, no. 2 (2014): 409-430.

Muttaqin, Husnul. "Relasi Agama dan Modernitas: Menggugat Teori Sekularisasi." Jurnal Sosiologi Islam 2, no. 2 (2012).

Mulkhan, Abdul Munir. "Spiritualisasi Lingkungan Materiel dan Moral Kenabian dalam Modernitas.” Unisia 30 (2016): 35-48.

Musnandar, Aries. "Manajemen Inklusif dengan Prinsip Maqâshid alSyarî́ah dalam Penghitungan Zakat dan Pajak." Ulul Albab 18, no. 2 (2017): 221. 
Muqoyyidin, Andik Wahyun. "Membangun Kesadaran InklusifMultikultural untuk Deradikalisasi Pendidikan Islam.” Jurnal Pendidikan Islam 2, no. 1 (2012).

Musyafa'ah, Nur Lailatul. "Pemikiran Fikih Wanita Qasim Amin.” Jurnal JS GI 4, no. 01: 2087-983.

Nonet, P., Shelznick, P. and Kagan, R. A. Law and Society in Transition: Toward Responsive Law. New York: Routledge, 2017.

Nurhadi, Agus. "Busana Muslim Seksi: Antara Modernitas dan Komersialisasi Agama.” Dalam Jurnal Analisa 20 (2005).

Prihatanto, Prihatanto. "Agama, Modernisasi, dan Teori Kritis: Sebuah Potret Pertautan." Unisia 30, no. 64 (2007).

Rheza, Bakhtiar Pamungkas. "Studi Pemikiran KHh. Sahal Mahfudh Tentang Konsep Maslahah dan Implementasinya salam Fikih Sosial." PhD diss., STAIN Pekalongan, 2016.

Rahim, Rahimin Affandi Abd, Paizah Ismail, dan Norhayati Mohd Dahlal, "Reformasi Undang-Undang Keluarga Islam di Malaysia: Satu Analisis Terhadap Gagasan Konsep Fiqh Semasa." International Journal of Mechanical and Materials Engineering (1970).

Rippin, A. Muslims: Their Religious Beliefs and Practices. New York: Routledge, 1993.

Sahidah, Ahmad, "Menemukan Islam Otentik: Menggugat Tradisi dan Modernitas." Kontekstualita: Jurnal Penelitian Sosial Keagamaan 25, no. 2 (2010).

Sirajudin, Sirajudin, "Integrasi Agama dan Sains; Islamisasi Sains di Tengah Arus Modernitas." Qolamuna: Jurnal Studi Islam 2, no. 1 (2016): 77-98.

Subhan, "Klasifikasi Ayat-ayat Hukum (dari Segi Qathi dan Zhanni)." Mazahib 12, no. 2 (2013).

Sunaryo, Agus, "Fikih Tasamuh: Membangun Kembali Wajah Islam yang Toleran." Akademika: Jurnal Pemikiran Islam 18, no. 2 (2013): 235-254.

, “Teologi Inklusif Nurcholis Madjid dan Pengaruhnya Terhadap Fikih Lintas Agama di Indonesia." Al-Manahij: Jurnal Kajian Hukum Islam 6, no. 1 (2012): 1-14. 
Susanto, Edi. "Spiritualisasi Pendidikan Agama Islam: Menuju Keberagamaan Inklusif Pluralistik." Nuansa: Jurnal Penelitian Ilmu Sosial dan Keagamaan Islam 11, no. 2 (2014).

Suryadinata, Muhammad. "Kepemimpinan Non-Muslim dalam al-Qur'ân: Analisis Terhadap Penafsiran FPI Mengenai Ayat Pemimpin NonMuslim.” Ilmu Ushuluddin 2, no. 3 (2016): 241-250.

Syarif, H. M., dan Mujar Ibnu. "Memilih Presiden Non-Muslim di Negara Muslim dalam Perspektif Hukum Islam." Jurnal Konstitusi 1, no. 1 (2008).

Silvita, Mary. "Presiden Non-Muslim dalam Komunitas Masyarakat Muslim." Islamica: Jurnal Studi Keislaman 7, no. 1 (2012): 44-60.

Tahir, Masnun. "Hak-hak Perempuan dalam Hukum Keluarga Syiria dan Tunisia." Al-Mawarid 18 (2008).

Umam, A. M. Al-Tajdîd Fi Al-Fikr Islâmi. Saudi Arabia: Darl Ibn Jauzi, 1424. Qaradawi, al-. al-Ijtihâd al-Mu'asir bain al-Inzibât wa al-Infirât. Kairo: Al-Maktab Al-Islami, 1998.

Wahidah, Nur Robi. "Fiqh Toleransi dalam Pespektif Al-Qur'an Departemen Agama RI." Maghza: Jurnal Ilmu Al-Qur'an dan Tafsir 1, no. 2 (2016): 99-114.

Wahyunadi, Zulham, and Raihanah HJ Azahari. "Perubahan Sosial dan Kaitannya dengan Pembagian Harta Warisan dalam Perspektif Hukum Islam." Jurnal Ilmiah Islam Futura14, no. 2 (2015): 166-189. Yusof, Abdullah, Rahimin Abd Rahim, Nor Adina Abdul Kadir, dan Nor Hayati Md Dahlal. "Konsep Feminisme Islam di dalam Film Ketika Cinta Bertasbih.” Journal of Al-Tamaddun 5 (2010): 131-147. Zuhaily, Wahbah al-. Subul al-Istifâdah. Damaskus: Darl al-Maktabi, 2001. , dan Athiyah, J. Tajdîd al-Figh al-Islâmi. Damaskus: Dar al-Fikr, 2000.

Zuhri, Saifudin. "Menempatkan Nilai-nilai Fikih Islam dalam Proses Modernisasi dan Perubahan Sosial Studi tentang Teori al-Tufi Mazhab Hanbali." Ijtihad: Jurnal Wacana Hukum Islam dan Kemanusiaan 14, no. 2 (2014): 167-187.

ZTF, Pradana Boy. Fikih Jalan Tengah: Dialektika Hukum Islam dan Masalah-masalah Masyarakat Modern. PT Grafindo Media Pratama, 2008. 